\title{
KEMANDIRIAN HAKIM DALAM MEMUTUS PERKARA KAITANNYA DENGAN LARANGAN MEMUTUS LEBIH DARI YANG DIMINTAKAN PARA PIHAK
}

\author{
Eka Aryanta $\mathrm{P}^{1}$, Agus Takariawan ${ }^{2}$, I Tajudin ${ }^{3}$ \\ Fakultas Hukum Universitas Padjadjaran Bandung \\ ekalitaparinding@gmail.com \\ DOI : https://doi.org/ 10.29313/shjih.v18i2.6829
}

\begin{abstract}
Abstrak
Keberadaan ketentuan Pasal 3 ayat (1) Undang-undang No. 48 Tahun 2009 tentang Kekuasaan Kehakiman yang merupakan dasar kemandirian hakim dalam memberikan putusan di pengadilan dapat dikatakan sulit untuk dilakukan mengingat pada umumnya putusan hakim biasanya didasarkan pada tuntutan jaksa. Keadaan ketika hakim memutus suatu perkara berdasarkan judex facti (Pengadilan Negeri dan Pengadilan Tinggi memiliki kewenangan memeriksa bukti-bukti dari suatu perkara dan menentukan fakta-fakta dari suatu perkara), maka tidak menutup kemungkinan putusannya melebihi tuntutan jaksa, dan hal tersebut dapat menimbulkan polemik, terlebih dengan adanya Peraturan Pemerintah Nomor 1 tahun 2016 Tentang Perubahan Kedua Atas UU Nomor 23 Tahun 2002 Tentang Perlindungan Anak yang memungkinkan hakim menjatuhkan hukuman kebiri bagi pelaku kejahatan seksual yang nyata-nyata mendapat pertentangan dari berbagai pihak termasuk jaksa karena sulit untuk mekakukan eksekusi.
\end{abstract}

Kata Kunci: Hakim, Kemandirian, Putusan Melebihi Tuntutan

\begin{abstract}
The existence of the provisions of Article Of The Act 3 Verse (1) No. 48 Years 2009 About Power Of Justice that is the independence of judges in ruling in court be hard to do considering that generally the judges usually based on demands. attorneyThe state when the judge decide a case based on judex facti (intermediate and lower courts have jurisdiction examine evidence of a matter and determine the facts of a matter), so it is possible the prosecutor, angels exceeds demand and that could cause, polemic especially with The Government Regulation No 12016 Years On The Second Year On Act No 232002 About Children Protection that allows the judge gave him capon for criminal sexual then find opposition from various parties including from prosecutors because it is hard to execution.
\end{abstract}

Keywords: Judge, Independency, The Award Exceeds Demands 


\section{A. Pendahuluan}

Landasan yuridis dan filosofis kekuasaan kehakiman sebagai lembaga yang mandiri dan bebas dari segala bentuk campur tangan dari luar, sebagaimana yang dikehendaki di dalam Pasal 24 UUD 1945, bahwa kekuasaan kehakiman adalah kekuasaan negara yang merdeka untuk menyeleggarakan peradilan guna menegakkan hukum dan keadilan berdasarkan Pancasila dan UUD 1945, demi terselenggaranya negara hukum Republik Indonesia. Oleh karena itu, hakim sebagai unsur inti dalam SDM yang menjalankan kekuasaan kehakiman di Indonesia, dalam menjalankan tugas pokok dan fungsi kekuasaan kehakiman wajib menjaga kemandirian peradilan melalui integritas kebebasan hakim dalam memeriksa dan memutus perkara sebagaimana diatur di dalam Pasal 39 ayat (4) UU No. 48 Tahun 2009.

Hakikat kebebasan hakim atau kemandirian kekuasaan kehakiman (independensi peradilan) itu bermaksud untuk mencegah penyalahgunaan wewenang dan kekuasaan oleh badan negara ${ }^{1}$. Sehubungan dengan ini Frans Magnis Suseno, ${ }^{2}$ mengemukakan bahwa dengan adanya kebebasan dan kemandirian kekuasaan kehakiman dari cabang kekuasaan negara lainnya, maka diharapkan bahwa badan yuridikatif dapat melakukan kontrol segi hukum terhadap kekuasaan negara disamping untuk mencegah dan mengurangi kecenderungan penyalahgunaan wewenang atau kekuasaan. Tidak hanya kemandirian kekuasaan kehakiman, terutama dari pengaruh kekuasaan pemerintah akan membuka peluang terjadinya penyalahgunaan kekuasaan dan pengabaian hak asasi manusia oleh penguasa karena kekuasaan kehakiman yang secara konstitusional memiliki wewenang untuk menjalankan fungsi kontrol terhadap kekuasaan pemerintah sulit menjalankan fungsi tersebut.

\footnotetext{
${ }^{1}$ Firman Floranta Adonara, Prinsip Kebebasan Hakim dalam Memutus Perkara Sebagai Amanat Konstitusi, Jurnal Konstitusi, Volume 12, Nomor 2, Juni 2015, hlm 230

${ }^{2}$ Frans Magnis Suseno, Etika Politik : Prinsip-Prinsip Moral Dasar Kenegaraan Modern , Jakarta: Gramedia, 1991, hlm 298-301.
} 
Langkah untuk memutus suatu perkara, hakim memiliki kemerdekaan dari campur tangan atau intervensi dari pihak manapun, yang dikenal dengan kekuasaan kehakiman yang merdeka, atau dapat diartikan sebagai kekuasaan kehakiman yang bebas dari campur tangan pihak manapun termasuk didalamnya kekuasaan pemerintah ${ }^{3}$.Kekuasaan kehakiman yang merdeka ini merupakan suatu kemandirian atau kemerdekaan yang dimiliki oleh lembaga peradilan demi terciptanya suatu putusan yang bersifat obyektif dan imparsial. Maksud dari sifat putusan yang obyektif adalah dalam proses pemberian putusan hakim harus berpendirian jujur, berpandangan yang benar atau berpandangan sesuai dengan keadaan yang sebenarnya dengan mengacu pada ukuran atau kriteria obyektif yang berlaku umum, sedangkan maksud dari putusan yang bersifat imparsial adalah putusan yang dihasilkan seorang hakim tidak memihak kepada salah satu pihak menimbulkan rasa ketidakadilan dari pihak-pihak yang berperkara atau bersengketa. Disamping itu keputusan yang diberikan tersebut secara langsung memberikan kepastian hukum dalam masyarakat. Jadi dapat disimpulkan kekuasaan kehakiman yang merdeka, harus menjamin terlaksananya peradilan yang jujur dan adil serta memenuhi kepastian hukum dalam masyarakat berdasarkan hukum yang berlaku.

Dalam upaya menemukan dan menerapkan keadilan dan kebenaran, putusan pengadilan harus sesuai dengan tujuan asasi dari suatu putusan pengadilan. Tujuan putusan pengadilan sejatinya ${ }^{4}$ :

1. Harus merupakan solusi autoritatif, artinya putusan haruslah memberikan jalan keluar dari masalah hukum yang dihadapi oleh para pihak.

${ }^{3}$ Restu Permadi, Fifiana Wisnaeni, Tinjauan Hukum Kemandirian Dan Independensi Mahkamah Agung Didalam Sistem Ketatanegaraan Indonesia, Jurnal Pembangunan Hukum Indonesia Volume 2, Nomor 3, Tahun 2020,hlm 404

${ }^{4}$ Yuristyawan Pambudi Wicaksana, Implementasi Asas Ius Curia Novit Dalam Penafsiran Hukum Putusan Hakim Tentang Keabsahan Penetapan Tersangka „Jurnal Lex Renaissance No. 1 Vol. 3 Januari 2018, hlm 93 
2. Karena keadilan yang tertunda adalah juga merupakan ketidakadilan (justice delayed is justice denied) maka putusan hakim harus mengandung efisiensi, yaitu cepat, sederhana dan biaya ringan.

3. Putusan hakim haruslah sesuai dengan tujuan undangundang yang dijadikan dasar putusan tersebut.

4. Putusan yang dibentuk harus mengandung aspek stabilitas yaitu ketertiban sosial dan ketentraman masyarakat.

5. Adanya pemberian kesempatan yang sama bagi para pihak yang berperkara

Dasar hukum tentang prinsip kebebasan hakim adalah Pasal 24 ayat (1)

UUD 1945 yang menentukan bahwa "Kekuasaan kehakiman merupakan kekuasaan yang merdeka untuk menyelenggarakan peradilan guna menegakkan hukum dan keadilan". Dalam interpretasi historis, dapat diketahui bahwa pasal tersebut oleh pembuatnya dimaksudkan bahwa lembaga peradilan bebas dari intervensi lembaga eksekutif atau lembaga dan perorangan. Prinsip yang terkandung didalamnya adalah bahwa kemerdekaan, kebebasan, atau kemandirian adalah bersifat kelembagaan, yaitu lembaga peradilan.

Mengenai prinsip kebebasan hakim sebagaimana dimaksudkan Pasal 32 ayat (5) Undang-undang No. 14 tahun 1985 tentang Mahkamah Agung (yang tidak dirubah oleh Undang-undang No.3 Tahun 2009 tentang Perubahan Kedua Atas Undang-undang No. 14 tahun 1985 tentang Mahkamah Agung), tidak dijelaskan lebih lanjut secara rinci oleh undang-undang tersebut, oleh karena itu semangat makna Pasal 24 ayat (1) UUD 1945 harus dikembangkan dalam memahami maksud kebebasan hakim dalam Pasal 32 ayat (5) Undang-undang No. 14 tahun 1945 tentang Mahkamah Agung (yang tidak dirubah oleh Undangundang No.3 Tahun 2009 tentang Perubahan Kedua Atas Undang-undang No. 14 tahun 1945 tentang Mahkamah Agung), bahwa kebebasan hakim harus dalam kerangka prinsip kebebasan lembaga peradilan.Karena hakim adalah sub sistem dari lembaga peradilan, sebagai pejabat yang melaksanakan kekuasaan kehakiman, sehingga kebebasan hakim haruslah selalu berada di dalam koridor kemerdekaan Kekuasaan Kehakiman, sebagaimana ditentukan di dalam Pasal 3 ayat (1) UU No. 48 Tahun 2009 tentang Kekuasaan Kehakiman, yang 
menyatakan bahwa: "Dalam menjalankan tugas dan fungsinya, hakim dan hakim konstitusi wajib menjaga kemadirian peradilan”.

Kekuasaan Kehakiman sendiri diartikan sebagai kekuasaan negara yang merdeka untuk menyelenggarakan peradilan guna menegakkan hukum dan keadilan berdasarkan Pancasila dan Undang-Undang Dasar Negara Republik Indonesia Tahun 1945, demi terselenggaranya negara hukum Republik Indonesia, hal ini dinyatakan dalam Pasal 1 ayat (1) UU No. 48 Tahun 2009 tentang Kekuasaan Kehakiman. Selain itu, perlu dikemukakan bahwa kekuasaan kehakiman dalam melaksanakan wewenang yudisial bersifat tidak mutlak karena tugas hakim adalah untuk menegakkan hukum dan keadilan berdasarkan Pancasila dan UUD 1945 sehingga putusannya mencerminkan rasa keadilan rakyat Indonesia, ${ }^{5}$ bukan keadilan subyektif menurut pengertian atau kehendak hakim semata. Namun, dalam pelaksanaannya kebebasan dan kemandirian yang diberikan kepada kekuasaan kehakiman (hakim) tersebut tidak dapat dilaksanakan sebagaimana mestinya. Hal tersebut disebabkan dalam menjalankan kemandiriannya hakim dibatasi oleh sistem pemerintahan, politik, dan ekonomi, serta peraturan perundang-undangan yang mengatur kemerdekaan tersebut.

Salah satu contoh kasus hukum mengenai kemandirian hakim adalah putusan No. 1616 K/Pid.Sus/2013, Mahkamah Agung telah mengoreksi putusan Pengadilan Tipikor Jakarta yang hanya menghukum terdakwa 4,5 tahun dari 12 tahun rekuisitor jaksa. Majelis hakim agung yang memeriksa perkara ini menjatuhkan putusan pidana penjara, denda, dan pengenaan uang pengganti yang sama dengan permintaan jaksa. Hakim hanya menambahkan hukuman pidana pengganti dari pidana denda berupa pidana kurungan. Hukuman dari hakim kasasi lebih tinggi dua bulan dari yang diminta. Hakim juga menjatuhkan pidana penjara pengganti jika uang pengganti tak dibayar, lebih tinggi dari tuntutan jaksa.

\footnotetext{
${ }^{5}$ Bambang Sutiyoso dan Sri Hastuti Puspitasari, Aspek-aspek Perkembangan Kekuasaan Kehakiman di Indonesia, Yogyakarta: UII Press, 2005, hlm 67
} 
Selain contoh kasus tersebut di atas, pemberian hukuman kebiri kimia bagi pelaku kejahatan seksual terhadap anak-anak oleh hakim terjadi di Kabupaten Mojokerto, Jawa Timur. Vonis hukuman itu dijatuhkan Pengadilan Negeri Mojokerto terhadap Muh Aris, pemuda asal Dusun Mengelo, Desa Sooko, Kecamatan Sooko, Kabupaten Mojokerto, Jawa Timur. Pengadilan memutuskan Aris bersalah melanggar Pasal 76 D junto Pasal 81 Ayat (2) Undang-undang RI Nomor 23 Tahun 2002 tentang Perlindungan Anak. Aris dihukum penjara selama 12 tahun dan denda Rp 100 juta subsider 6 bulan kurungan. Selain itu, Aris dikenakan hukuman tambahan berupa kebiri kimia. Aris dihukum penjara dan kebiri kimia setelah terbukti melakukan 9 kali pemerkosaan di wilayah Kota dan Kabupaten Mojokerto. Ada pun para korbannya merupakan anak-anak. ${ }^{6}$

Dalam mempertimbangkan vonis yang lebih berat tersebut majelis hakim agung mencantumkan pertimbangan-pertimbangan. Majelis hakim, menurut peneliti, bisa menggunakan keadilan subtantif. Menurut Sudikno Mertokusumo, hakim itu bebas dalam atau untuk mengadili sesuai dengan hati nuraninya/keyakinannya tanpa dipengaruhi oleh siapapun. Hakim bebas memeriksa, membuktikan dan memutuskan perkara berdasarkan hati nuraninya. Disamping itu juga bebas dari campur tangan pihak ekstra yudisial ${ }^{7}$. Segala campur tangan dalam urusan peradilan oleh pihak-pihak lain di luar kekuasaan kehakiman dilarang, kecuali dalam hal-hal yang tersebut dalam UUD 1945. Tetapi di dalam praktik ketentuan itu tidak jarang dilanggar, antara lain dengan mengambil jalan pintas dengan menggunakan surat sakti, telepon sakti, suap dan

\footnotetext{
${ }^{6}$ Robbi Khadafi, "Cabut Pasal Hukuman Kebiri pada Pelaku Kejahatan Seksual”, diakses melalui https://www.kompasiana.com/robbikhadafi/5d6338860d823037e24389c2/cabut-pasalhukuman-kebiri-pada-pelaku-kejahatan-seksual\#, pada tanggal 5 November 2019

7 Sudikno Mertokusumo, Sistem Peradilan di Indonesia, Jurnal Hukum FH-UII, Jakarta,1997, hlm 5
} 
sebagainya ${ }^{8}$. Hoentink mengatakan bahwa, hakim tidak boleh mengadili melulu menurut perasaan keadilan diri pribadinya, melainkan ia terikat kepada nilainilai yang berlaku secara obyektif di dalam masyarakat. Scholten mengatakan bahwa, hakim terikat pada sistem hukum yang telah terbentuk dan berkembang di dalam masyarakat. Dengan tiap-tiap putusannya hakim menyatakan dan memperkuat kehidupan norma-norma hukum yang tidak tertulis ${ }^{9}$.

Keadaan apabila hakim sudah merasa cukup dalam memeriksa perkara yang diajukan kepadanya, maka tibalah saatnya ia akan memberikan putusan atas perkara yang diajukan. Dalam memutus perkara tersebut disyaratkan dalam undang-undang bahwa disamping berdasarkan alat-alat bukti yang sudah ditentukan oleh undangundang, juga harus berdasarkan pada keyakinan hakim. Untuk menentukan adanya keyakinan ini tidaklah mudah bagi hakim dalam menjalankan tugas profesinya. Keadaan demikian dikhawatirkan jika hakim salah dalam menentukan keyakinannya, maka akan terjadi kesesatan yang mengakibatkan putusan hakim menjadi tidak adil.

Mengkaji ketentuan Pasal 3 ayat (1) Undang-undang No. 48 Tahun 2009 tentang Kekuasaan Kehakiman yang memberikan ruang kemandirian hakim dalam memberikan putusan di pengadilan tentunya sangat sulit untuk dilakukan karena berbagai tekanan baik batin sendiri hakim ataupun tekanan dari pihak lain kemungkinan terjadi. hal ini haruslah disikapi secara arif dan bijak mengingat putusan hakim tersebut mencerminkan suatu keadilan.

Keberadaan ketentuan Pasal 3 ayat (1) Undang-undang No. 48 Tahun 2009 tentang Kekuasaan Kehakiman yang merupakan dasar kemandirian hakim dalam memberikan putusan di pengadilan dapat dikatakan sulit untuk dilakukan mengingat pada umumnya putusan hakim biasanya didasarkan pada tuntutan jaksa. Keadaan ketika hakim memutus suatu perkara berdasarkan judex facti

\section{${ }^{8}$ Idem}

${ }^{9}$ I.G.N. Soegangga, Pengantar Hukum Adat Semarang: Badan Penerbit Undip, 1994, hlm 
(Pengadilan Negeri dan Pengadilan Tinggi memiliki kewenangan memeriksa bukti-bukti dari suatu perkara dan menentukan fakta-fakta dari suatu perkara), maka tidak menutup kemungkinan putusannya melebihi tuntutan jaksa, dan hal tersebut dapat menimbulkan polemik.

Berdasarkan latar belakang di atas maka penulis melakukan identifikasi masalah sebagai berikut:

a. Bagaimana kedudukan hakim dalam memutus suatu perkara dihubungkan dengan kemandirian hakim berdasarkan peraturan perundang-undangan?

b. Bagaimana konsep putusan hakim yang berisikan ultra petita yang memberikan keadilan?

\section{B. Metode Penelitian}

Jenis Penelitian yang penulis gunakan adalah penelitian yuridis normatif. Sifat penelitian yang penulis gunakan dalam penelitian hukum ini adalah deskriptif. Sifat Deskriptif terlihat dari permasalahan yang akan dibahas mengenai bagaimana pelaksanaan praperadilan yang gugatannya dilakukan oleh pihak ketiga dalam praktik peradilan pidana Indonesia serta bagaimana kedudukan pihak ketiga sebagai pemohon gugatan praperadilan dalam sistem peradilan pidana Indonesia. Data yang penulis gunakan adalah data primer dan data sekunder.

\section{Hasil dan Analisis}

\section{Kedudukan Hakim Dalam Memutus Suatu Perkara Dihubungkan Dengan Kemandirian Hakim Berdasarkan Peraturan Perundang-Undangan}

Hakim merupakan jabatan yang mempunyai tugas memeriksa dan memutus suatu perkara. Hakim pada khususnya, dan lembaga peradilan pada umumnya, diharapkan memiliki peran sentral dalam penegakan hukum ditengah 
terik ulur kepentingan politik dan ekonomi ${ }^{10}$. Seseorang yang memiliki jabatan sebagai Hakim tentunya juga menjalankan tugas untuk memeriksa dan memutus suatu perkara. Memeriksa dan memutus suatu perkara tidaklah semudah orang menentukan suatu tujuan. Tugas memeriksa dan memutuskan perkara merupakan tugas yang dilakukan oleh seorang yang berdiri di tengah-tengah diantara mereka yang berperkara. Berdiri ditengah-tengah diantara mereka yang berperkara tentunya berdiri dengan tegak, tidak condong dan dalam posisi imbang.

Kunci utama menjalankan peran di tengah-tengah adalah bahwa putusan yang diambilnya menjadi putusan yang dapat diterima oleh kedua belah pihak yang berperkara dengan senang. Inilah inti persoalan keadilan itu dalam suatu putusan Hakim. Bagi para Hakim di Indonesia mustinya sudah paham benar tentang keadilan dalam hal ini. Oleh karenanya semestinya dalam memutuskan suatu perkara istilah kalah dan menang haruslah dihindari.

Keadaan apabila dihadapkan pada siatuasi perkara yang berhubungan dengan perbuatan seseorang yang merugikan kepentingan umum atau melanggar hak asasi orang lain, maka pada dasarnya hal tersebut terkait dengan persoalan perbuatan pidana yaitu perbuatan yang dilarang dan diancam dengan sanksi pidana oleh undang-undang bagi barangsiapa yang melanggar larangan tersebut. Bila persoalannya sudah menyangkut persoalan perbuatan pidana tentunya putusan Hakim sangat terkait dengan persoalan salah atau tidak salah (guilty or not guilty) ${ }^{11}$.

\footnotetext{
${ }^{10}$ Ismail Rumadan, Peran Lembaga Peradilan Sebagai Institusi Penegak Hukum Dalam Menegakkan Keadilan Bagi Terwujudnya Perdamaian, Jurnal Rechstvinding, Volume 6, Nomor 1, April 2017, hlm 77

11 Mohammad, Kajian Hukum Atas Jaminan Keamanan Dan Kesejahteraan Hakim Menurut PP Nomor 94 Tahun 2012 Tentang Hak Keuangan Dan Fasilitas Hakim Yang Berada Di Bawah Mahkamah Agung, Jurnal Yustitia Vol. 20 No. 2 Desember 2019, hlm 131
} 
Sistem peradilan merupakan sistem penanganan perkara sejak adanya pihak yang merasa dirugikan atau sejak adanya sangkaan seseorang telah melakukan perbuatan pidana hingga pelaksanaan putusan Hakim. Khusus bagi sistem peradilan pidana, sebagai suatu jaringan, sistem peradilan pidana mengoperasionalkan hukum pidana sebagai sarana utama, dan dalam hal ini berupa hukum pidana materiil, hukum pidana formil dan hukum pelaksanaan pidana.

Sistem peradilan pidana lebih banyak menempatkan peran Hakim dihadapkan pada tuntutan pemenuhan kepentingan umum (publik) dan penentuan nasib seseorang, ketimbang perkara yang lain. Oleh karenanya terjadinya suatu perbuatan pidana menimbulkan dampak pada munculnya tugas dan wewenang para penegak hukum untuk mengungkap siapa pelaku sebenarnya (aktor intelektual) dari perbuatan pidana tersebut.

Mengungkap siapa pelaku yang sebenarnya tidaklah semudah orang membalik telapak tangan apabila peristiwa pidana yang terjadi bukanlah suatu perbuatan tertangkap tangan. Oleh karenanya untuk mengungkap kebenaran dari peristiwa pidana yang terjadi sangatlah diperlukan bukti-bukti yang kuat dan akurat yang mendukung kebenaran peristiwanya.

Bukti-bukti yang kuat dan akurat inilah yang dibutuhkan oleh para penegak hukum untuk menyeret pelakunya guna diminta pertanggungjawabannya. Para penegak hukum memang pihak yang tidak tahu menahu tentang peristiwa pidana yang terjadi, namun memiliki tanggungjawab untuk mengungkap kebenaran suatu peristiwa yang sudah berlalu.

Oleh karenanya dalam mengungkap kebenaran peristiwanya para penegak hukum dibantu dengan bukti-bukti yang kuat dan dengan bukti-bukti inilah kebenaran akan terungkap meskipun tidak 100\%, namun setidak-tidaknya mendekati peristiwa yang sebenarnya karena peristiwa yang sudah belalu tidaklah mungkin untuk diulang kembali. Dalam kedudukannya yang demikian inilah sebenarnya Hakim sebagai salah satu penegak hukum memiliki posisi yang paling menguntungkan ketimbang pihak Polisi (Penyidik) dan Jaksa (Penuntut Umum). Polisi dan Jaksa dapat dituntut oleh pihak Tersangka atau 
Terdakwa bila apa yang dilakukan terhadap Tersangka atau Terdakwa salah, sedangkan Hakim tidak dapat dituntut bila salah dalam menjatuhkan putusan.

Tanggungjawab ini memanglah tidak mudah dan penuh resiko bila salah dalam melakukan tindakannya. Resiko yang diemban apabila menjatuhkan putusan pidana mati, namun ternyata yang dijatuhi pidana mati itu bukanlah pelaku yang sebenarnya. Siapa yang dapat mengembalikan nyawa seseorang yang telah dipidana mati, namun ternyata salah atas pelakunya. Perintah pencabutan nyawa seseorang akan memiliki tanggungjawab yang berat, tidak hanya pada saat dirinya hidup namun juga nanti saat dirinya di akherat.

Begitu beratnya tanggungjawab Hakim dalam memeriksa dan memutus perkara menempatkan Hakim pada kedudukan yang mulia. Dalam sistem peradilan pidana Hakim memiliki kedudukan sebagai pejabat yang memeriksa dan memutus perkara pidana yang diajukan kepadanya. Oleh karena kedudukannya yang demikian itu Hakim dihadapkan pada beberapa asas hukum yang melekat pada jabatannya itu antara lain:

a. Hakim (pengadilan) tidak boleh menolak perkara yang diajukan kepadanya dengan dalih hukumnya tidak jelas (Pasal 16 KUHAP). Ketentuan asas ini menjelaskan bahwa seorang Hakim yang disodori sebuah perkara maka ia wajib memeriksanya, dan tidak diperkenankan menolak dengan dalih hukumnya tidak jelas namun Hakim harus dapat membuktikan kebenaran dari peristiwa pidana yang terjadi atas perkara yang diajukan kepadanya, dan ia harus dapat menemukan hukumnya;

b. Apa yang telah diputus oleh Hakim harus dianggap benar (res judicata proveritate habetur). Ketentuan ini mengindikasikan bahwa Hakim dalam memutuskan suatu perkara yang diajukan kepadanya merupakan keputusan yang benar, karena Hakim melihat dari bukti-bukti yang sah yang diajukan kepadanya, dan didukung dengan keyakinannya atas kesalahan pelaku atas dasar bukti-bukti yang ada.

c. Hakim harus mengadili, bukan membuat hukum (judicis est jus dictare, non dare). Hal ini untuk menentukan bahwa seorang Hakim tugas utamanya adalah memeriksa dan memutus suatu perkara yang didasarkan pada bukti- 
bukti yang sah dan keyakinannya akan kebenaran berdasarkan pada buktibukti sah tersebut, sehingga putusannya dapat dipertanggungjawabkan dan dianggap adil. Hakim tak dibenarkan menjatuhkan putusan tanpa didasarkan pada bukti-bukti dan membuat putusan yang harus ditaati oleh para pihak yang berperkara. Meskipun demikian dalam mengadili suatu perkara Hakim menentukan hukumnya in konkreto, sehingga putusan Hakimpun dapat dianggap sebagai hukum (jude made law), namun dalam pembentukan hukum tersebut putusan Hakim dibatasi oleh undang-undang dan terikat oleh undang-undang.

d. Tidak ada Hakim yang baik dalam perkaranya sendiri (nemo judex idoneus in propria causa). Ketentuan ini mengisyaratkan agar Hakim dalam memeriksa perkara haruslah perkara yang tidak ada hubungan dengan dirinya dan keluarganya, artinya Hakim yang memeriksa perkara tidak boleh memiliki kepentingan atas perkara tersebut karena pihak-pihak yang berperkara masih mempunyai hubungan darah atau semenda (persaudaraan) dengan Hakim.

Beberapa asas yang disebutkan di atas menjadi landasan dalam menjalankan tugas memeriksa dan memutus perkara. Tugas memeriksa dan memutus perkara bukanlah tugas yang ringan, apalagi berkaitan dengan perkara pidana, Hakim harus bisa menempatkan dirinya pada objektivitas perkara yang dihadapkan kepadanya. Hakim harus cermat dalam memeriksa perkara tersebut dan dapat membuktikan bahwa perkara pidana yang diajukan kepadanya itu benar-benar perkara yang bukan hasil rekayasa dan tidak diwarnai oleh kepentingan-kepentingan lain terutama kepentingan politik ${ }^{12}$.

Dalam memeriksa perkara pidana, Hakim memiliki kedudukan dan tugas yang amat berat, dirinya dihadapkan pada peristiwa pidana yang sudah berlalu dan tidak mungkin untuk diulang kembali. Untuk membuktikan kebenaran akan

${ }^{12}$ Ismail Eka Syahrial, Kesesuaian Alasan Pengajuan Peninjauan Kembali Dalam Tindak Pidana Penipuan Dengan Ketentuan Kuhap (Studi Kasus Putusan Mahkamah Agung Nomor 36 PK/PID/2013), Jurnal Verstek Volume 5 Nomor 2 Tahun 2016, hlm 105 
peristiwa inilah Hakim haruslah dibantu oleh alat-alat bukti yang medukung kebenaran akan peristiwa pidananya. Namun demikian undang-undang menentukan pula disamping alat bukti harus didukung dengan keyakinan Hakim berdasarkan alat bukti tersebut (Pasal 183 KUHAP), inilah yang dalam sistem pembuktian sering disebut sebagai negatief wettelijk system.

Keyakinan Hakim yang didukung dengan alat bukti yang sah menurut undang-undang merupakan urusan hati nurani Hakim dalam menentukan adanya kebenaran, dan juga merupakan urusan hati nurani Hakim dalam menunjukkan kemandiriannya, serta independensinya memutus perkara yang dipertanggungjawabkan kepada publik, masyarakat umum bahwa dirinya tidak memihak siapapun. Inilah kedudukan Hakim yang amat berat dalam sistem peradilan pidana, karena disamping ketidak berpihakannya juga urusan hati nuraninya dipertaruhkan. Ketidak berpihakan akan nampak dari putusan yang dijatuhkan, tetapi urusan hati nurani hanya Tuhan lah yang dapat mengetahuinya.

Mempertanyakan putusan pidana yang dijatuhkan Hakim kepada pelaku kejahatan dengan pertanyaan-pertanyaan berkisar pada pantaskah pelaku dijatuhi pidana 5 tahun misalnya, atau 10 tahun atau hukuman mati bahkan pada saat ini pemberian putusan pengkebirian pun dapat dilakukan yang mendapat tanggapan minor dari banhak kalangan termasuk Ikatan Dokter Indonesia dan jaksa itu sendiri. Putusan-putusan ini menjadi kewenangan penuh Hakim, serta tidak seorangpun boleh campur tangan atas putusan Hakim tersebut. Oleh karenanya yang dapat menjawab pertanyaan-pertanyaan tersebut hanya Hakim sendiri yang menjatuhkan putusan yang bersangkutan. Seberapa pantaskah pelaku mendapat pidana? Hati nurani Hakimlah yang berbicara. Bila Hakim sudah tidak ingat akan hati nurani yang dimilikinya, maka tercorenglah citra Hakim di mata masyarakat luas

Menyikapi kemandirian hakim di indonesia dengan mengkaji peraturan perundangan yang ada, maka mendasarkan pada Pasal 24 Ayat (1) UUD NRI 1945 yang berbunyi: "kekuasaan kehakiman merupakan kekuasaan yang merdeka untuk menyelenggarakan hukum dan keadilan”. Jaminan konstitusional 
(constitutional independence) ini diimplementasikan melalui beberapa pengaturan terkait independensi hakim dalam UU Kekuasaan Kehakiman, UU Mahkamah Agung, UU Mahkamah Konstitusi, UU Komisi Yudisial sebagai berikut:

a. Independensi Hakim Dalam Kaitannya Dengan Kemandirian Hakim Dalam Undang-Undang Nomor 48 Tahun 2009 tentang Kekuasaan Kehakiman

Dalam Pasal 1 UU R.I. Nomor 4 tahun 2004 jo Pasal 1 angka 1 Undangundang Nomor 48 Tahun 2009 tentang Kekuasaan Kehakiman disebutkan bahwa Kekuasaan kehakiman adalah kekuasaan Negara yang merdeka untuk menyelenggarakan peradilan guna menegakkan hukum dan keadilan berdasarkan Pancasila dan Undang-Undang Dasar Negara Republik Indonesia Tahun 1945, demi terselenggaranya Negara Hukum Republik Indonesia.

Kekuasaan kehakiman merupakan kekuasaan yang berdiri sendiri dan bebas dari campur tangan pihak-pihak di luar kekuasaan kehakiman untuk menyelenggarakan peradilan demi terselenggaranya negara hukum ${ }^{13}$. Oleh karenanya dalam Pasal 4 ayat (3) Undang-undang Nomor 4 tahun 2004 jo Pasal 3 ayat (2) Undang-Undang Nomor 48 Tahun 2009 tentang Kekuasaan Kehakiman ditentukan bahwa segala campur tangan dalam urusan peradilan oleh pihak lain di luar kekuasaan kehakiman dilarang, kecuali dalam hal-hal sebagaimana dimaksud dalam Undang-Undang Dasar Negara Republik Indonesia tahun 1945.

b. Independensi Hakim Dalam Kaitannya Dengan Kemandirian Hakim Dalam Undang-undang Mahkamah Agung

Kekuasaan kehakiman merupakan salah satu bentuk kekuasaan tertinggi di Indonesia (prime power). Kekuasaan kehakiman adalah kekuasaan negara yang merdeka untuk menyelenggarakan peradilan guna menegakkan hukum dan keadilan berdasarkan Pancasila dan Undang-Undang Dasar Negara Republik

${ }^{13}$ Sudikno Mertokusumo, Hukum Acara Perdata Indonesia, Edisi Keempat, Yogyakarta: Liberty, 1998, hlm 18. 
Indonesia Tahun 1945, demi terselenggaranya Negara Hukum Republik Indonesia $^{14}$

Peran Mahkamah Agung dapat kita temukan dalam Pasal 2 Undangundang Nomor 14 Tahun 1985 yang berbunyi:

"Mahkamah Agung adalah Pengadilan Negara Tertinggi dari semua Lingkungan Peradilan, yang dalam melaksanakan tugasnya terlepas dari pengaruh pemerintah dan pengaruh-pengaruh lain."

Di dalam penjelasan umum Undang-undang No. 3 tahun 2009 dikatakan pula bahwa Mahkamah Agung adalah pengadilan negara tertinggi dari semua lingkungan peradilan yang berada di bawahnya. Oleh karena itu, MA melakukan pengawasan tertinggi terhadap badan peradilan dalam lingkungan peradilan umum, lingkungan peradilan agama, lingkungan peradilan militer, dan lingkungan peradilan tata usaha negara. Oleh karenanya itu, Kekuasaan kehakiman dibawah Mahkama Agung, diakui sebagai kekuasaan yang harus independen (merdeka) dari berbagai anasir, intervensi, maupun intimidasi dari pihak lain yang dapat mengganggu proses hukum yang sedang berjalan.

Kebebasan dan kemandirian hakim (A freedom and independency judiciary) harus diwujudkan secara konkrit, walaupun tidak berarti bebas sebebas-bebasnya. Mekanisme check and balances, check and control harus didorong dan diciptakan untuk menghindari adanya power blocks. Pemindahan kewenangan pembinaan dan pengawasan terhadap hakim dalam aspek organisasi, administrasi, dan keuangan pengadilan ke Mahkamah Agung (Undang-Undang Nomor 35 Tahun 1995), tanpa diikuti dengan perubahan sistem pengawasan yang baik terhadap pelaksaan kekuasaan kehakiman, terdapat peluang besar bagi penyalahgunaan kewenangan (abuse of power) oleh Mahkamah Agung ${ }^{15}$.

${ }^{14}$ Pasal 1 Angka (1) Undang-undang Nomor 48 Tahun 2009 Tentang Kekuasaan

${ }^{15}$ Abdul Manan, "Kemandirian Lembaga Peradilan dan Supremasi Hukum di Indonesia" majalah hukum USU,Februari 2004. hlm.121 
c. Independensi Hakim Dalam Kaitannya Dengan Kemandirian Hakim Dalam Undang-undang Mahkamah Konstitusi

Perubahan Pasal 24 ayat (2) dan Pasal 24C amandemen ketiga UndangUndang Dasar Republik Indonesia Tahun 1945 (UUD 1945) memisahkan antara kekuasaan kehakiman dalam ranah peradilan umum dengan peradilan perlindungan konstitusionalitas ${ }^{16}$. Peradilan umum dilaksanakan oleh Mahkamah Agung dan badan peradilan dibawahnya. Sedangkan peradilan konstitusionalitas dilaksanakan oleh Mahkamah Konstitusi sebagai lembaga kekuasaan kehakiman di luar Mahkamah Agung.

Hal ini berarti Mahkamah Konstitusi terikat pada prinsip umum penyelenggaraan kekuasaan kehakiman yang merdeka, bebas dari pengaruh kekuasaan lembaga lainnya dalam menegakkan hukum dan keadilan. Sesuai dengan Pasal 2 Undang-undang No. 24 tahun 2003 bahwa "Mahkamah Konstitusi merupakan salah satu lembaga negara yang melakukan kekuasaan kehakiman yang merdeka untuk menyelenggarakan peradilan guna menegakkan hukum dan keadilan."

Mahkamah Konstitusi diberikan kewenangan melakukan pengujian undang-undang terhadap UUD. Sedangkan pengujian peraturan perundangundangan dibawah undang-undang terhadap undang-undang diberikan kepada Mahkamah Agung. Menurut Jimly Asshiddiqie, Mahkamah Konstitusi menguji the constitutionality of legislative law or legislation, sedangkan Mahkamah Agung menguji the legality or regulation ${ }^{17}$. Sehingga pengujian undang-undang

\footnotetext{
${ }^{16}$ Feri Amsari, Perubahan UUD 1945, Perubahan Konstitusi Negara Kesatuan Republik Indonesia Melalui Keputusan Mahkamah Konstitusi, Jakarta: RajaGrafindo Persada, 2011, hlm. 160.

17 Jimly Asshiddiqie, Hukum Acara Pengujian Perundang-Undangan di Mahkamah Konstitusi, dalam Pusat Studi Konstitusi FHUA, Perkembangan Pengujain Perundang-Undangan di Mahkamah Konstitusi dalam Jurnal Konstitusi,Vol. 7 No. 6, Desember 2010, hlm. 5
} 
dibagi ke dalam dua kekuasaan kehakiman yaitu Mahkamah Konstitusi dan Mahkamah Agung.

Prinsip independensi yang termuat dalam Kode Etik dan Perilaku Hakim Konstitusi telah peraturan Mahkamah Konstitusi Republik Indonesia Nomor 09/pmk/2006 Tentang Pemberlakuan Deklarasi kode etik dan perilaku hakim Konstitusi bahwa:

"Independensi hakim konstitusi merupakan prasyarat pokok bagi terwujudnya cita negara hukum, dan merupakan jaminan bagi tegaknya hukum dan keadilan. Prinsip ini melekat sangat dalam dan harus tercermin dalam proses pemeriksaan dan pengambilan keputusan atas setiap perkara, dan terkait erat dengan independensi Mahkamah sebagai institusi peradilan yang berwibawa, bermartabat, dan terpercaya. Independensi hakim konstitusi dan pengadilan terwujud dalam kemandirian dan kemerdekaan hakim konstitusi, baik sendirisendiri maupun sebagai institusi dari pelbagai pengaruh, yang berasal dari luar diri hakim berupa intervensi yang bersifat memengaruhi secara langsung atau tidak langsung berupa bujuk rayu, tekanan, paksaan, ancaman, atau tindakan balasan karena kepentingan politik, atau ekonomi tertentu dari pemerintah atau kekuatan politik yang berkuasa, kelompok atau golongan tertentu, dengan imbalan atau janji imbalan berupa keuntungan jabatan, keuntungan ekonomi, atau bentuk lainnya."

d. Independensi Hakim Dalam Kaitannya Dengan Kemandirian Hakim Dalam UU Komisi Yudisial

Kehadiran Komisi Yudisial (KY) berdasarkan Undang-Undang Dasar 1945 setelah perubahan ke IV. Pasal 24 B menjadi dasar hokum kelahiran KY yang dalam tugas pokoknya mengusulkan pengangkatan hakim agung dan menjaga dan menegakkan kehormatan, keluhuran martabat, serta perilaku hakim. Kedua kewenangan ini merupakan landasan yang dijiwai oleh semangat 
terjadinya check dan balances, saling mengimbangi dan saling kontrol di antara lembaga yang ada, termasuk Mahkamah Agung. ${ }^{18}$

Jika Mahkamah Agung dan Mahkamah Konstitusi sebagai lembaga penegak hukum, maka Komisi Yudisial adalah lembaga yudikatif yang bersifat penunjang terhadap lembaga kekuasaan kehakiman. Komisi Yudisial bukanlah lembaga penegak hukum (code of law), melainkan lembaga penegak norma etik (code of ethics) ${ }^{19}$. Pada Pasal 2 Undang-undang No. 22 tahun 2004 bahwa "Komisi Yudisial merupakan lembaga negara yang bersifat mandiri dan dalam pelaksanaan wewenangnya bebas dari campur tangan atau pengaruh kekuasaan lainnya".

Komisi Yudisial adalah lembaga negara yang mempunyai peranan penting dalam usaha mewujudkan kekuasaan kehakiman yang merdeka melalui pencalonan hakim agung serta pengawasan terhadap hakim yang transparan dan partisipatif untuk menegakkan kehormatan dan keluhuran martabat, serta menjaga perilaku hakim, sebagaimana dimaksud dalam Undang-Undang Dasar Negara Republik Indonesia Tahun 1945. Komisi Yudisial merupakan lembaga negara yang bersifat mandiri dan dalam pelaksanaan wewenangnya bebas dari campur tangan atau pengaruh kekuasaan lainnya, yang berkedudukan di Jakarta.

Berhasil tidaknya suatu Komisi Yudisial ini tidaklah diukur karena banyaknya hakim yang dipecat, melainkan tugas Komisi Yudisial adalah untuk mengembalikan spirit independensi kekuasaan kehakiman agar sesuai dengan spirit untuk menegakkan hukum dan keadilan. Dengan demikian, apapun putusan hakim pada dasarnya haruslah dapat dilaksanakan, karena pada dasarnya

${ }^{18}$ Tutik Triwulan Titik, Eksistensi Kedudukan dan Wewenang Komisi Yudisial sebagai Lembaga Negara dalam Sistem Ketatanegaraan Republik Indonesia Pasca Amandemen UUD 1945, Jakarta: Prestasi Pustaka Publisher, 2007, hlm 95.

${ }^{19}$ Suparto, Perbandingan Model Komisi Yudisial Komisi Yudisial Republik Indonesia Dengan Komisi Yudisial Perancis Indonesia Dengan Komisi Yudisial Perancis, Jurnal UIR Law Review, Volume 03, Nomor 01, April 2019, hlm 22 
pula putusan hakim tersebut merupakan hasil dari pertimbangan hukum yang dilakukan hakim yang disandarkan pada peraturan perundang-undangan yang berlaku. Namun demikian hal yang semestinya diperhatikan oleh hakim adalah keberadaan pranata hukum dalam pelaksanan putusan yang dikeluarkannya karena bisa saja putusan hakim tersebut tidak dapat dilaksanakan oleh elemen pendukung lainnya. Hal tersebut terjadi pada pemberian hukuman kebiri kimia yang merupakan penyuntikan terhadap seorang laki-laki dengan obat-obatan yang secara efektif menyebabkan tumpulnya gairah seks untuk jangka waktu tertentu ${ }^{20}$, jaksa yang sulit untuk mengeksekusi pelaku karena keterbatasa kewenangan yang didasarkan pada aturan yang ada ketika eksekusi itu harus dilakukan, di lain sisi Ikatan Dokter Indonesia yang merupakan elemen yang ditunjuk sebagai eksekutor pun menolak dengan alasan melanggar kode etik. Hal seperti ini lah yang seharusnya mendapat perhatian hakim dalam memutuskan suatu perkara, sehingga tidak menjadi diskursus di masyarakat atas putusan hakim yang dikeluarkannya.

\section{Analisis Konsep Putusan Hakim Yang Berisikan Ultra Petita Yang Memberikan Keadilan}

Sebagaimana diketahui, dalam penegakan hukum ada tiga unsur yang selalu berkaitan dan haruslah diperhatikan, karena satu sama lainnya harus berimbang, yaitu keadilan, kepastian hukum, dan kemanfaatan. Letak strategis putusan hakim untuk menjadi penegak hukum yang mandiri sebagaimana amanat Undang-Undang Dasar Negara Republik Indonesia Tahun 1945 tanpa diintimidasi kekuasaan apapun, yang kemudian dijabarkan dan tertuang dalam Undang-Undang Nomor 48 tahun 2009 tentang Kekuasaan Kehakiman di mana dalam Pasal 1 menyatakan:

“Kekuasaan Kehakiman adalah kekuasaan Negara yang merdeka untuk menyelenggaraakan peradilan guna menegakkan hukum dan keadilan

${ }^{20}$ Aditia Arief Firmanto, Kedudukan Pidana Kebiri Dalam Sistem Pemidanaan Di Indonesia (Pasca Dikeluarkanya Perppu No. 1 TAHUN 2016), Jurnal Hukum Novelty, Vol. 8 No. 1 Februari 2017, hlm 6 
berdasarkan Pancasila, demi terselenggaranya Negara Hukum Republik Indonesia",

Kemudian dalam Pasal 10 Undang-Undang Nomor 48 tahun 2009 tentang Kekuasaan Kehakiman menyebutkan:

"Pengadilan dilarang menolak untuk memeriksa, mengadili, dan memutus suatu perkara yang diajukan dengan dalih bahwa hukum tidak ada atau kurang jelas, melainkan wajib memeriksa dan mengadilinya."

Mendasarkan pada ketentuan Pasal 10 Undang-Undang Nomor 48 tahun 2009 tentang Kekuasaan Kehakiman maka jelaslah bahwa Pengadilan dilarang menolak suatu perkara apakah karena tidak ada hukumnya ataupun karena hukumnya yang kurang jelas, karena oleh Pasal 5 Undang-Undang Nomor 48 tahun 2009 tentang Kekuasaan Kehakiman disebutkan bahwa "Hakim dan hakim konstitusi wajib menggali, mengikuti dan memahami nilai-nilai hukum dan rasa keadilan yang hidup dalam masyarakat".

Seorang hakim dalam menjalankan fungsi yudisialnya bukan hanya sebagai terompetnya undang-undang, yang menganggap pasal - pasal hukum sebagai satu-satunya sumber hukum, namun lebih jauh hakim juga haruslah berani bertindak sebagai penemu hukum sebagaimana diamanatkan UndangUndang Dasar Negara Republik Indonesia Tahun 1945 yang kemudian dijabarkan oleh Undang-Undang Nomor 48 tahun 2009 tentang Kekuasaan Kehakiman, di mana hakim diharuskan memiliki kemampuan untuk mengeksplorasi nilai-nilai keadilan dalam masyarakat untuk kemudian pertimbangannya tersebut dituangkan dalam bentuk putusan- putusannya yang dapat dijadikan acuan yang berupa Yurisprudensi.

Pengetahuan hukum yang harus dikuasai hakim sesungguhnya harus haruslah multidisplin, yang melintasi hukum acara, hukum materiil, ilmu hukum, filsafat hukum, sosiologi hukum, psikologi hukum, ilmu komunikasi, hukum adat, metodologi hukum dan lain - lain.

Sebagaimana diketahui, bentuk-bentuk penyelesaian perkara melalaui pengadilan salah satunya berupa putusan. Adapun bentuk penyelesaian perkara melalui pengadilan ini dibedakan menjadi dua macam yaitu : Putusan (vonnis, arrest) da penetapan (bechikking). Hakim sebagai pengadil sering berhadapan 
pada suatu ketentuan yang belum diatur, yang disebabkan karena terhambatnya upaya mewujudkan sistem hukum nasional yang mantap. Banyak peraturan perundang-undangan yang merupakan warisan dari kolonial maupun peraturan perundang-undangan yang baru dibuat dan disahkan akan tetapi tidak sesuai dengan perkembangan masyarakat yang penuh dengan dinamika perubahan yang terjadi. Disisi lain badan peradilan dalam hal ini hakim tidak boleh menolak untuk memeriksa, mengadili dan memutuskan suatu perkara yang diajukan kepadanya dengan dalih bahwa hukumnya tidak ada atau kurang jelas.

Hakim dalam menjalankan fungsinya menjalankan tugas penting di mana hakim harus dapat menyesuaikan undang-undang dengan perkembangan yang hidup di masyarakat, jika undang-undang tidak dapat dijalankan menurut arti katanya, hakim wajib menafsirkan sehingga dibuat suatu putusan yang memenuhi rasa keadilan dan sesuai dengan maksud hukum. Hakim selalu dihadapkan pada peristiwa konkrit dimana hakim harus memberikan jalan keluar atau memberikan suatu pertimbangan yang dapat diterima secara nalar dalam suatu putusannya yang mempunyai kekuatan mengikat sebagai hukum dan menjadi suatu sumber hukum ( yurisprudensi).

Sistem hukum indonesia tidak menentukan jenis klasifikasi yurisprudensi tertentu untuk dijadikan sumber hukum, akan tetapi di dalam praktek peradilan dikenal adanya klasifikasi yurisprudensi biasa dan yurisprudensi tetap. Kedua klasifikasi yurisprudensi itu memerlukan kriteria sendiri agar dengan cara itu dapat ditelusuri sejauh mana hubungan kedua klasifikasi yurisprudensi itu dalam proses penegakan hukum. Sudikno mertokusumo memberikan 2 (dua) kategori, sebagai yurisprudensi tetap, yakni: a Bahwa dalam putusan hakim ditemukan adanya kaidah hukum yang dapat dianggap sebagai - landmark decision karena putusan tersebut mengandung kaidah hukum yang diterima masyarakat luas sebagai teroboosan yang nyata atas suatu konflik hukum yang sudah berlangsung lama. 
b Kaidah hukum atau ketentuan dalam suatu putusan kemudian diikuti secara konstan dan tetap oleh para hakim lainnya dalam putusannya dan dapat dianggap menjadi bagian dari keyakinan hukum yang umum. ${ }^{21}$

Mendasarkan pada uraian tersebut di atas, dapat dikatakan bahwa kriteria yurisprudensi tetap adalah telah mentranformasikan secara konstan hukum yang hidup dalam suatu masyarakat dan telah tertuang dalam sebuah putusan hakim yang kemudian diikuti oleh berbagai putusan hakim sesudahnya, sehingga yurisprudensi tetap tersebut telah melakukan penciptaan hukum.

Sebagai hakim yang melakukan penemuan hukum dalam putusannya, harus menguasai metode yang dapat dipergunakan, yaitu melalui penerapan hukum penafsiran dan konstruksi hukum, penafsiran atau interpretasi adalah usaha memberi makna suatu atau sejumlah kaidah hukum agar dapat diterapkan secara wajar dalam memecahkan suatu persoalan hukum. Terdapat bermacammacam metode penafsiran berdasarkan tata bahasa atau ilmu bahasa, penafsiran sistematik, penafsiran berdasarkan sejarah perundang-undangan yang bersangkutan, penafsiran berdasarkan sejarah hukum, penafsiran teleologis, penafsiran antisipasif dan penafsiran dinamika-evolutif. Selaian itu, mengkahi konstruksi hukum dalam suatu perkara di Pengadilan, sekalipun hakim dapat menafsirkan, namun tidak ada ketentuan perundang-undangan yang berlaku yang dapat diterapkan, juga tidak ada ketentuan dalam hukum kebiasaan dan hukum adat yang dapat diterapkan, maka keadaan ini mulai menyangkut kepada keadaan kekosongan hukum dalam sistem formil hukum.

Hakim bukanlah mulutnya undang-undang atau mulut hukum positif pada umumnya, demikian pula hakim tidak sekedar menerapkan bunyi suatu perjanjian yang merupakan undang-undang bagi pihak-pihak yang membuatnya, hakim sudah seharusnya menjadi mulut keadilan, kepatutan, kepentingan umum dan ketertiban umum.

${ }^{21}$ H.P. PanggabeanPenerapan Teori Hukum Dalam Sistem Peradilan Indonesia. Bandung: Alumni, 2014, hlm. 235. 
Asas ini menunjukkan bahwa sebagai hakim tidak boleh semata-mata mencari dan menemukan kebenaran formil, termasuk dalam perkara-perkara keperdataan, hakim harus mencari dan menemukan kebenaran materiil. Walaupun demikian apabila hakim dihadapkan pada pilihan antara ketentuan hukum tertulis (hukum positif) dengan hukum tidak tertulis, maka hakim atau siapapun juga yang menerapkan hukum, harus mengutamakan atau mendahulukan ketentuan hukum tertulis, akan tetapi penerapan hukum tertulis ini harus mempertimbangkan hal-hal sebagai berikut:

a. Mengutamakan atau mendahulukan hukum tertulis apabila diketahui atau secara wajar dan rasional dipahami bahwa ketentuan hukum tertulis (hukum positif) merupakan pembaharuan terhadap hukum tidak tertulis atau terjadi transformasi ketentuan hukum tidak tertulis menjadi hukum tertulis (hukum positif);

b. Mengutamakan atau mendahulukan hukum tidak tertulis, apabila ketentuan hukum tidak tertulis merupakan suatu yang tumbuh dan kemudian menjadi suatu koreksi atau penafsiran terhadap suatu ketentuan aturan hukum tertulis. Koreksi ini merupakan kenyataan hukum yang hidup dalam masyarakat dan dapat terjadi karena hukum tertulis yang telah usang atau ada kekosongan tertentu dalam ketentuan hukum tertulis, atau jika aturan hukum tertulis (hukum positif) tersebut memunculkan ketidak adilan, melanggar kepatutan, kepentingan umum dan ketertiban umum.

Idealnya suatu putusan hakim itu harus memuat idee des recht, yang meliputi 3 (tiga) unsur yaitu : keadilan (gerechttigkeit), kepastian hukum (rechtsicherheit), dan kemanfaatan (zwechtmassigkeit). Ketiga unsur ini harus dipertimbangkan hakim dan diterapkan secara proporsional, sehingga akan menimbulkan kemandirian hakim dalam membuat suatu keputusan serta dapat dihasilkan putusan yang berkualitas dan memenuhi harapan pencari keadilan. Namun dalam implementasinya terkadang tidaklah mudah untuk mensinergikan ketiga unsur tersebut, terutama antara unsur keadilan dengan kepastian hukum yang bisa saja saling bertentangan, namun demikian hakim dalam hal ini haruslah berpegang teguh kepada asas yang mendasar dalam sebuah putusan 
yakni "Demi Keadilan Berdasarkan Ketuhanan Yang Maha Esa", jadi hakim dalam putusannya haruslah mengedepankan keadilan karena putusannya tersebut dipertanggung jawabkannya kepada Tuhan Yang Maha Esa.

Putusan hakim yang menggambarkan benturan antara aspek keadilan dengan kepastian hukum, tentunya seorang hakim akan lebih memilih aspek keadilan sehingga akhirnya hakim akan menyimpangi aspek kepastian hukum dalam hal ini hukum tertulis (hukum positif), guna hal tersebut hakim haruslah memantapkan dirinya menjadi profesionalisme dalam mewujudkan putusan yang berkualitas, dengan menghasilkan putusan-putusan yang eksekutable yang berisikan integritas tinggi, memuat pertimbangan yuridis yang utama, beriintikan rasa keadilan dan kebenaran, sesuai dengan tata nilai budaya yang berlaku dalam masyarakat, dapat diterima akal sehat (ethos, pathos, filosofis, sosiologis, serta logos).

\section{Simpulan}

1. Kedudukan hakim dalam memutus suatu perkara dihubungkan dengan kemandirian hakim berdasarkan peraturan perundang-undangan pada dasarnya pada dasarnya apapun putusan hakim haruslah dapat dilaksanakan karena pada dasarnya pula putusan hakim tersebut merupakan hasil dari pertimbangan hukum yang dilakukan hakim yang disandarkan pada peraturan perundang-undangan yang berlaku. Namun demikian hal yang semestinya diperhatikan oleh hakim adalah keberadaan pranata hukum dalam pelaksanan putusan yang dikeluarkannya karena bisa saja putusan hakim tersebut tidak dapat dilaksanakan oleh elemen pendukung lainnya. Hal tersebut terjadi pada pemberian hukuman kebiri kimia, jaksa yang sulit untuk mengeksekusi pelaku karena keterbatasa kewenangan yang didasazrkan pada aturan yang ada ketika eksekusi itu harus dilakukan, di lain sisi Ikatan Dokter Indonesia yang merupakan elemen yang ditunjuk sebagai eksekutor pun menolak dengan alasan melanggar kode etik. Hal seperti ini lah yang seharusnya mendapat perhatian hakim dalam memutuskan suatu perkara, sehingga tidak menjadi diskursus di masyarakat atas putusan hakim yang dikeluarkannya. 
2. Konsep putusan hakim yang berisikan ultra petita yang memberikan keadilan adalah didasarkan pada asas dasar sebuah putusan yakni "Demi Keadilan Berdasarkan Ketuhanan Yang Maha Esa", oleh karena itu terlepas apakah putusan hakim tersebut mengandung unsur ultra petita atau tidak maka unsur keadilan yang harus diutamakan oleh hakim. Hhal tersebut merupakan amanat yang terkandung dalam Pasal 1 Undang-Undang Nomor 48 tahun 2009 tentang Kekuasaan Kehakiman tentangv kekuasaan kehakiman. 


\section{DAFTAR PUSTAKA}

Abdul Manan, "Kemandirian Lembaga Peradilan dan Supremasi Hukum di Indonesia" majalah hukum USU,Februari 2004.

Aditia Arief Firmanto, Kedudukan Pidana Kebiri Dalam Sistem Pemidanaan Di Indonesia (Pasca Dikeluarkanya Perppu No. 1 TAHUN 2016), Jurnal Hukum Novelty, Vol. 8 No. 1 Februari 2017.

Bambang Sutiyoso dan Sri Hastuti Puspitasari, Aspek-aspek Perkembangan Kekuasaan Kehakiman di Indonesia, Yogyakarta: UII Press, 2005.

Feri Amsari, Perubahan UUD 1945, Perubahan Konstitusi Negara Kesatuan Republik Indonesia Melalui Keputusan Mahkamah Konstitusi, Jakarta: RajaGrafindo Persada, 2011.

Firman Floranta Adonara, Prinsip Kebebasan Hakim dalam Memutus Perkara Sebagai Amanat Konstitusi, Jurnal Konstitusi, Volume 12, Nomor 2, Juni 2015.

Frans Magnis Suseno, Etika Politik : Prinsip-Prinsip Moral Dasar Kenegaraan Modern, Jakarta: Gramedia, 1991.

H.P. PanggabeanPenerapan Teori Hukum Dalam Sistem Peradilan Indonesia. Bandung: Alumni, 2014.

I.G.N. Soegangga, Pengantar Hukum Adat Semarang: Badan Penerbit Undip, 1994.

Ismail Eka Syahrial, Kesesuaian Alasan Pengajuan Peninjauan Kembali Dalam Tindak Pidana Penipuan Dengan Ketentuan Kuhap (Studi Kasus Putusan Mahkamah Agung Nomor 36 PK/PID/2013), Jurnal Verstek Volume 5 Nomor 2 Tahun 2016.

Ismail Rumadan, Peran Lembaga Peradilan Sebagai Institusi Penegak Hukum Dalam Menegakkan Keadilan Bagi Terwujudnya Perdamaian, Jurnal Rechstvinding, Volume 6, Nomor 1, April 2017.

Jimly Asshiddiqie, Hukum Acara Pengujian Perundang-Undangan di Mahkamah Konstitusi, dalam Pusat Studi Konstitusi FHUA, Perkembangan Pengujain Perundang-Undangan di Mahkamah Konstitusi dalam Jurnal Konstitusi,Vol. 7 No. 6, Desember 2010.

Mohammad, Kajian Hukum Atas Jaminan Keamanan Dan Kesejahteraan Hakim Menurut PP Nomor 94 Tahun 2012 Tentang Hak Keuangan Dan Fasilitas 
Hakim Yang Berada Di Bawah Mahkamah Agung, Jurnal Yustitia Vol. 20 No. 2 Desember 2019.

Restu Permadi, Fifiana Wisnaeni, Tinjauan Hukum Kemandirian Dan Independensi Mahkamah Agung Didalam Sistem Ketatanegaraan Indonesia, Jurnal Pembangunan Hukum Indonesia Volume 2, Nomor 3, Tahun 2020.

Robbi Khadafi, "Cabut Pasal Hukuman Kebiri pada Pelaku Kejahatan Seksual”, diakses melalui https://www.kompasiana.com/robbikhadafi/5d6338860d823037e24389c2/ cabut-pasal-hukuman-kebiri-pada-pelaku-kejahatan-seksual\#, pada tanggal 5 November 2019

Sudikno Mertokusumo, Sistem Peradilan di Indonesia, Jurnal Hukum FH-UII, Jakarta,1997.

, Hukum Acara Perdata Indonesia, Edisi Keempat, Yogyakarta: Liberty, 1998.

Suparto, Perbandingan Model Komisi Yudisial Komisi Yudisial Republik Indonesia Dengan Komisi Yudisial Perancis Indonesia Dengan Komisi Yudisial Perancis, Jurnal UIR Law Review, Volume 03, Nomor 01, April 2019

Tutik Triwulan Titik, Eksistensi Kedudukan dan Wewenang Komisi Yudisial sebagai Lembaga Negara dalam Sistem Ketatanegaraan Republik Indonesia Pasca Amandemen UUD 1945, Jakarta: Prestasi Pustaka Publisher, 2007.

Yuristyawan Pambudi Wicaksana, Implementasi Asas Ius Curia Novit Dalam Penafsiran Hukum Putusan Hakim Tentang Keabsahan Penetapan Tersangka ,Jurnal Lex Renaissance No. 1 Vol. 3 Januari 2018. 